\title{
Efficiency of application in diets of high-productive cows of Actisaf SC 47
}

\author{
Alexander Aristov ${ }^{1 *}$, Lidia Esaulova ${ }^{1}$, Nikolay Zuev ${ }^{1}$, and Natalya Gorbunova ${ }^{2}$ \\ ${ }^{1}$ Voronezh state agrarian University. Peter. Voronezh, Russia \\ ${ }^{2}$ Belgorod State National Research University. Belgorod, Russia
}

\begin{abstract}
The paper discusses the technology of growing, keeping and feeding dairy cows in the conditions of Zolotaya Niva LLC, one of the largest high-tech dairy complex in the Smolensk region, a European type for the production of raw cow milk, which has the status of pedigree producer. The structure of the feed and the quality of mixing are determined by means of the Pennsylvania sorting system, the level of feed on the sieves is in line with the normative. The results of the production experiment on feeding dairy cows with Actisaf Sc 47, which has a probiotic effect, indicate better digestibility of the feed when the additive is introduced, the use of the drug contributes to: reducing ketone bodies in milk, the beneficial effect of improved feeding, by including yeast on the health of animals, improving the health of the udder, manifested in a decrease in somatic cells in milk. The milk yield with the use of the additive is increased, the milk protein is also increased, since its absorption in the rumen is improved. With the use of additives, the appetite and eatability of the feed improves, so in the group before feeding the probiotic, the percentage of feed residue on the feed table is higher than in the experiment. Dry matter intake is $4.32 \%$ higher when feeding supplements, while feed conversion is increased. Saving feed costs per $1 \mathrm{~kg}$ of milk is 0.97 rubles. Saving feed costs per year for a livestock of 1800 animals will amount to 523,800 rubles.
\end{abstract}

\section{Introduction}

Dairy farming ranks third in terms of production intensity after poultry and pig breeding in the Russian Federation. Great importance is attached to the quality of dairy products in the markets of various levels. This indicator is determined by various factors, including the level and quality of feeding. In the correction of the last one, feed additives play an important role.

Livestock is considered one of the most profitable industries and needs quality feed and supplements to meet its nutrient needs. In addition, these feeds must be of high quality for a wide range of their indicators, such as the presence of nutrients, vitamins, macro- and microelements, amino acids, as well as the absence or minimization of harmful and toxic substances. However, a large number of crops are exposed to toxigenic fungi that produce mycotoxins that are harmful to the health of both animals and humans.

Therefore, the purpose of this study is to determine the effectiveness of a new probiotic feed additive on feed digestibility, the content of ketone bodies in milk, udder health, manifested in a decrease in somatic cells in milk, appetite and feed intake.

To achieve this goal, it was necessary to solve the following tasks:

1. Examine the level of feeding of cows;

2. Conduct research on the level of ketone bodies and their derivatives in the body of cows;

3. To study the effect of the feed additive Actisaf Sc 47 on the productivity of cows, the level of ketone bodies, biological and technological properties of milk.

\footnotetext{
* Corresponding author: alevas75@mail.ru
}

\section{Experimental}

The experiment on feeding the additive Actisaf Sc 47 was carried out by the method of groups - periods. The experiment involved 166 cows from the 14th day of lactation. The studies were carried out in the control group without the use of probiotics. Then the results were evaluated in the experimental one 18 days after the application of the probiotic and twice more with an interval of five days. The next study was carried out 36 days after the end of feeding the probiotic (control 2).

The drug was introduced into the diets of dairy cows in the amount of 5 grams per head per day, at a cost of 1 $\mathrm{kg}$ of yeast for wholesale buyers 630 rubles per kilogram, the price per head per day will be:

$$
\begin{aligned}
& 1000 \mathrm{~g}-630 \text { rubles } \\
& 5 \mathrm{~g}-\mathrm{x} \text { rub } \\
& \mathrm{X}=3.15 \text { rubles }
\end{aligned}
$$

During the experiment, the following indicators were determined: feed digestibility, determination of the level of beta-hydroxybutyric acid, determination of somatic cells in milk, milk productivity and the qualitative composition of milk, consumption of dry matter of the diet.

\section{Results and discussions}

The research was carried out at Zolotaya Niva LLC. This is a high-tech dairy complex of European type with its own feed base for the production of raw cow's milk - one of the largest in the Smolensk region.

The enterprise has the status of a pedigree breeding unit. The loose housing of livestock is used on the farm. 
The herd was formed at the expense of Holstein-Friesian heifers purchased in Europe and the USA.

After calving, the first food for the calf is colostrum (it needs to be drunk within 30 minutes). Colostrum quality is checked before soldering using a refractometer. A high Brix value means good colostrum. Good colostrum should contain at least $22 \%$. The next dairy feed after colostrum is pasteurized milk 3 liters $\mathrm{x} 3 \mathrm{r}$ per day. Along with milk, they begin feeding granular pre-starter compound feed from Trouw Nutrition.

The farm uses corn silage, grass haylage, rolled corn grain as the main forage for feeding dairy cows. Concentrated feed is fed in the form of a compound feed a concentrate, which includes dry granulated beet pulp, rapeseed meal, soybean meal, corn gluten, chalk, soda, salt, palm fat, targeted premix for dairy cows, blood meal, fungisorb adsorbent, urea and syrup. The feed is mixed in a mixer wagon and distributed in the form of fully mixed feed mixtures on the feed table. Determination of the structure of feed and the quality of mixing is carried out according to the Pennsylvania sorting system (table 1) [1].

Analyzing the data in the table, we note that the level of feed on the sieves corresponds to the standard. Deviation from the norm is observed only in the first sieve, this can be explained by the addition of green mass and large granules of dry beet pulp. An excess on the top sieve is allowed, provided that the feed is well eaten. It is also possible to indicate the homogeneity of the feed, the percentage of differences between sample 1 and sample 2 does not exceed $4.4 \%$ and is noted on the upper sieve.

A production experiment on feeding dairy cows with Actisaf Sc 47 additive was carried out on the farm. Actisaf Sc 47 is a thermo-stable concentrate of Saccharomyces cerevisiae live yeast. The specialists of the Lesaffre group selected this strain 30 year ago specifically for animal feeding. When feeding cattle, live yeast accelerates the synthesis of free fatty acids and reduces the ammonia content in the rumen, creates an anaerobic environment in the rumen, which promotes the growth of cellulolytic bacteria that process lactic acid.

This process allows you to control the $\mathrm{pH}$ level, stimulates the scar microflora to better digest the coarse lignified fiber of bulky, poor quality feed, such as straw. Allows you to get more energy from bulk feed, available for milk production or gaining weight gain [2].

Digestibility of feed - by means of washing the manure on sieves (table 2).

It can be seen from Table 2 that fewer whole grains were observed in the test samples than in the control.

The total residue on the sieves in the test samples was less than in the control, while with an increase in the duration of the experiment, the remainder of the feed on the sieves decreased, which indicates a better digestibility of feed [3]. Determining the level of beta-hydroxybutyric acid (beta-hydroxybutyrate) in milk is an effective tool for detecting elevated ketone body levels in cows. Ketosis occurs when the concentration of BOMA increases. The results of the analysis of milk by test strips for betahydroxybutyrate are presented in Table 3 . The data in the table show that the minimum level of ketone bodies is recorded in the milk of animals at the early stage of lactation, the maximum amount is recorded at the peak of productivity, but the use of the drug helps to reduce ketone bodies. One of the main reasons for the increase in the content of somatic substances in milk is mastitis [4]. Determination of the number of somatic cells in milk was carried out using the somatos device (table 4).

The obtained data on the presence of somatic cells in the milk of the experimental group indicate the health of the udder of the cows of the experimental group and the beneficial effect of improving feeding, through the inclusion of yeast, on the health of animals, which is manifested in a decrease in somatic cells in milk.

As a result of consuming the probiotic, cicatricial digestion is improved. The influence of the probiotic on milk productivity and the qualitative composition of milk is presented in table 5 .

It can be seen from the data in the table that the milk yield with the use of the probiotic increases, the milk protein also increases, since its absorption in the rumen improves.

The farm regularly monitors the consumption of dry matter by cows by the difference in the mass of the distributed and eaten feed, as well as the content of dry matter in the feed mixture [5]. The control of dry matter consumption by cows is presented in Table 6 .

It can be seen from the table that in cows using the Aktisaf additive, appetite and feed intake improve, so in the control group, before feeding the probiotic, the percentage of feed residue on the feed table is higher than in the experiment. Consumption of dry matter is $4.32 \%$ higher in the experiment.

It can be seen from the table that in cows using the Aktisaf additive, appetite and feed intake improve, so in the control group, before feeding the probiotic, the percentage of feed residue on the feed table is higher than in the experiment. Consumption of dry matter is $4.32 \%$ higher in the experiment.

The table shows that in connection with the improvement of cicatricial nutrition, the consumption of dry matter by animal's increases, while milk yield increases. The feed conversion is increased. The cost of 1 $\mathrm{kg}$ of milk decreases (Table 7).

It can be seen from the table that in cows using the Aktisaf additive, appetite and feed intake improve, so in the control group, before feeding the probiotic, the percentage of feed residue on the feed table is higher than in the experiment. Consumption of dry matter is $4.32 \%$ higher in the experiment. 
Table 1. Results of separation of a fully mixed ration of a highly productive group of cows.

\begin{tabular}{|c|c|c|c|c|c|}
\hline \multirow{2}{*}{ Total sample } & \multirow{2}{*}{ Norm } & \multicolumn{2}{|c|}{ Sample No. 1 } & \multicolumn{2}{c|}{ Sample No. 2 } \\
\cline { 2 - 6 } & & $842 \mathrm{~g}$ & $100 \%$ & $801 \mathrm{~g}$ & $100 \%$ \\
\hline The 1st sieve & $2-8$ & $131 \mathrm{~g}$ & $15.5 \%$ & $159 \mathrm{~g}$ & $19,9 \%$ \\
\hline The 2nd sieve & $30-50$ & $308 \mathrm{~g}$ & $36.6 \%$ & $264 \mathrm{~g}$ & $33 \%$ \\
\hline The 3rd sieve & $10-20$ & $127 \mathrm{~g}$ & $15.1 \%$ & $112 \mathrm{~g}$ & $14 \%$ \\
\hline Bin filler & $30-40$ & $276 \mathrm{~g}$ & $32.8 \%$ & $266 \mathrm{~g}$ & $33 \%$ \\
\hline
\end{tabular}

Table 2. Results of manure flushing (goal less residue on sieves).

\begin{tabular}{|c|c|c|c|c|c|}
\hline \multirow{2}{*}{ Indicators } & $\begin{array}{c}\text { Control (no } \\
\text { probiotic) }\end{array}$ & \multicolumn{3}{|c|}{ Experience (Probiotic Use) } & $\begin{array}{c}\text { Control, no yeast } \\
\text { probiotic }\end{array}$ \\
\cline { 2 - 6 } & 29.11 .19 & 18.12 .19 & 24.12 .19 & 30.12 .19 & 03.02 .20 \\
\hline Total sample, g & 617 & 646 & 606 & 529 & 585 \\
\hline Top sieve, g & 28 & 83 & 64 & 48 & 80 \\
\hline Top sieve, \% & 4.5 & $12.8^{*}$ & 10.5 & 9.1 & 13.7 \\
\hline Lower sieve, g & 125 & 53 & 59 & 53 & 46 \\
\hline Lower sieve, \% & 20.3 & 8.2 & 9.7 & 10 & 101 \\
\hline $\begin{array}{c}\text { Total residue on } \\
\text { sieves, g }\end{array}$ & 153 & 136 & 123 & 126 \\
\hline $\begin{array}{c}\text { Total residue on } \\
\text { sieves, \% }\end{array}$ & 24.8 & 21 & 20.2 & 19.1 & 21.5 \\
\hline
\end{tabular}

Table 3. Results of analysis of milk for beta-hydroxybutyrate.

\begin{tabular}{|c|c|c|c|c|c|c|c|c|c|}
\hline \multirow{2}{*}{\multicolumn{2}{|c|}{$\begin{array}{c}\text { Control (no probiotic) } \\
29.11 .19\end{array}$}} & \multicolumn{6}{|c|}{ Experience (Probiotic Use) } & \multirow{2}{*}{\multicolumn{2}{|c|}{$\begin{array}{c}\begin{array}{c}\text { Control, no yeast } \\
\text { probiotic }\end{array} \\
06.02 .20\end{array}$}} \\
\hline & & \multicolumn{2}{|c|}{ 18.12.19 } & \multicolumn{2}{|c|}{24.12 .19} & \multicolumn{2}{|c|}{ 30.12.19 } & & \\
\hline $\begin{array}{l}\text { Animal } \\
\text { number }\end{array}$ & $\begin{array}{c}\text { BGB mg } \\
/ \text { dl }\end{array}$ & $\begin{array}{l}\text { Animal } \\
\text { number }\end{array}$ & $\begin{array}{c}\text { BGB mg / } \\
\text { dl }\end{array}$ & $\begin{array}{l}\text { Animal } \\
\text { number }\end{array}$ & $\begin{array}{c}\text { BGB mg / } \\
\text { dl }\end{array}$ & $\begin{array}{l}\text { Animal } \\
\text { number }\end{array}$ & $\begin{array}{c}\text { BGB mg / } \\
\text { dl }\end{array}$ & $\begin{array}{l}\text { Animal } \\
\text { number }\end{array}$ & $\begin{array}{c}\text { BGB } \\
\mathrm{mg} / \mathrm{dl}\end{array}$ \\
\hline 1844 & 1 & 4722 & 1 & 9650 & 1 & 1836 & 0.5 & 3826 & 1 \\
\hline 3033 & 1 & 4148 & 1 & 3866 & 0.5 & 5317 & 1 & 7220 & 1 \\
\hline 5046 & 0 & 1402 & 1 & 5149 & 1 & 4183 & 1 & 1402 & 0.5 \\
\hline 5400 & 0 & 914 & 1 & 3171 & 1 & 3272 & 0.5 & 3272 & 1 \\
\hline 3522 & 1 & 3436 & 1,5 & 3848 & 1 & 2257 & 1 & 2257 & 0.5 \\
\hline 2287 & 0 & 4216 & 1 & 4911 & 1 & 2842 & 0.5 & 2842 & 0.5 \\
\hline 3968 & 1 & 3272 & 1 & 7220 & 1 & 4177 & 1 & 4548 & 0.5 \\
\hline 1402 & 1 & 1760 & 1,5 & 718 & 1 & 5258 & 1 & 5258 & 0.5 \\
\hline 8539 & 1 & 4548 & 1 & 3624 & 0.5 & 8523 & 1 & 8523 & 0.5 \\
\hline 4289 & 0 & 1402 & 1 & 4301 & 1 & 3132 & 0 & 3624 & 1 \\
\hline $\mathrm{M} \pm \mathrm{M}$ & $0.6 \pm 0.52$ & & $1.1 \pm 0.21$ & & $0.9 \pm 0.21$ & & $0.75 \pm 0.35$ & & $0.7 \pm 0.26$ \\
\hline
\end{tabular}

Table 4. Content of somatic cells in milk obtained during the experiment.

\begin{tabular}{|c|c|c|c|c|}
\hline \multirow{2}{*}{$\begin{array}{c}\text { Control } \\
\text { (no probiotic) 29.11.19 }\end{array}$} & \multicolumn{3}{|c|}{ Experience (Probiotic Use) } & $\begin{array}{c}\text { Control, no yeast } \\
\text { probiotic }\end{array}$ \\
\cline { 2 - 5 } & 18.12 .19 & 24.12 .19 & 30.12 .19 & 06.02 .20 \\
\hline $193 \mathrm{~K}$ & $182 \mathrm{~K}$ & $149 \mathrm{~K}$ & $136 \mathrm{~K}$ & $129 \mathrm{~K}$ \\
\hline
\end{tabular}

Table 5. Milk productivity and quality composition of milk.

\begin{tabular}{|l|c|c|c|}
\hline \multirow{2}{*}{ Control (no probiotic) } & & yield of milk & 32.3 \\
\cline { 3 - 4 } & \multirow{2}{*}{$\mathbf{2 9 . 1 1 . 1 9}$} & fats, \% & 3.9 \\
\cline { 3 - 4 } & & protein, \% & 3.31 \\
\hline Experience (Probiotic Use) & $\mathbf{1 8 . 1 2 . 1 9}$ & yield of milk & 34.4 \\
\hline
\end{tabular}




\begin{tabular}{|c|c|c|c|}
\hline & & fats, $\%$ & 3.9 \\
\hline & & protein, $\%$ & 3.31 \\
\hline & \multirow{3}{*}{ 24.12.19 } & yield of milk & 36.3 \\
\hline & & fats, \% & 3.9 \\
\hline & & protein, $\%$ & 3.37 \\
\hline & \multirow{3}{*}{ 30.12.19 } & yield of milk & 36.2 \\
\hline & & fats, $\%$ & 3,9 \\
\hline & & protein, $\%$ & 3.38 \\
\hline \multirow{3}{*}{ Control, no yeast probiotic } & \multirow{3}{*}{ 06.02.20 } & yield of milk & 37 \\
\hline & & fats, $\%$ & 3.9 \\
\hline & & protein, $\%$ & 3.38 \\
\hline
\end{tabular}

Table 6. Control of consumption of dry matter.

\begin{tabular}{|c|c|c|}
\hline Group & Control & Experience \\
\hline $\begin{array}{c}\text { Livestock } \\
\text { The mass of the distributed } \\
\text { feed, kg/day }\end{array}$ & 166 & 8268.79 \\
\hline Residue weight, kg & 8268.79 & 248.06 \\
\hline $\begin{array}{c}\text { \% of residues } \\
\text { khe mass of the eaten feed, }\end{array}$ & 578.82 & 3 \\
\hline $\begin{array}{c}\text { The mass of the eaten feed, } \\
\text { kg /animal }\end{array}$ & 7 & 8020.73 \\
\hline $\begin{array}{c}\text { \% DM in feed mixture } \\
\text { TM consumption per animal }\end{array}$ & 7689.98 & 48.32 \\
\hline
\end{tabular}

Table 7. Economic efficiency of the drug 'ACTISAF SC-47'.

\begin{tabular}{|c|c|c|}
\hline & Control & Experience with Actisaf Sc 47 \\
\hline Dry matter consumed in the diet, $\mathbf{k g}$ & 23.16 & 24.16 \\
\hline Milk received, kg / animal / day & 32.30 & 36.20 \\
\hline Milk is obtained from 1 kg of dry matter & 1.39 & 1.50 \\
\hline Ration cost & 317.00 & 320.15 \\
\hline Cost of 1 kg of milk, rub & 9.81 & 8.84 \\
\hline Saving feed costs per 1 kg of milk, rubles & & 0.97 \\
\hline
\end{tabular}

\section{Conclusion}

The digestibility of feed with the introduction of the additive and the use of the drug helps to reduce ketone bodies in milk, has a beneficial effect on improving feeding, improves udder health, which is manifested in a decrease in somatic cells in milk. Milk yield with the use of the additive increases, the protein content in milk also increases, as its assimilation in the rumen improves.
Appetite and feed intake are improved with the use of the additive, so in the group before feeding the probiotic, the percentage of feed residue on the feed table is higher than in the experiment. Dry matter consumption is $4.32 \%$ higher when the additive is fed, while the feed conversion is increased. Savings in feed costs per $1 \mathrm{~kg}$ of milk is 0.97 
rubles. Savings in feed costs per year for a livestock of 1,800 heads will amount to 523,800 rubles.

\section{References}

1. V. Pryadko, Sieve for feed. Determine the structure of the feed, 10.26.2016. URL: http://www.progressivefarm.info/2016/10/26/sitadlya-kormov-opredelyaem-strukturnost-korma (accessed: 01/22/2020).

2. A. Bedenko, Live yeast in compound feeds for cows. URL: https://studylib.ru/doc/2388500/zhivyedrozhzhi-v-kombikormah-dlya-korov (accessed: 01/22/2020).

3. Luke Marisink, Washing manure on sieves. URL: https: //soft-agro.com/krs-na-otkorme/promyvanienavoza-na-sitax.html (accessed date: 01/22/2020).
4. V. Bochenkov, High level of somatic cells in milk: causes and how to reduce them, 05/10/2018 URL: http://milkfermer.ru/somaticheskie-kletki-v-molokeprichiny-i-kak-snizit/ (date of treatment : 01/22/2020).

5. The amount of feed that the cow actually eats. URL: https://soft-agro.com/korovy/kolichestvo-kormakotoroe-fakticheski-poedaet-korova.html (accessed: 01/22/2020). 